University of Louisville

ThinkIR: The University of Louisville's Institutional Repository

Electronic Theses and Dissertations

$5-2012$

\title{
Mad at Miles : a black woman's guide to truth : theatre building using myths, motifs, and archetypes.
}

Triza Triza Cox

University of Louisville

Follow this and additional works at: https://ir.library.louisville.edu/etd

\section{Recommended Citation}

Cox, Triza Triza, "Mad at Miles : a black woman's guide to truth : theatre building using myths, motifs, and archetypes." (2012). Electronic Theses and Dissertations. Paper 282.

https://doi.org/10.18297/etd/282

This Master's Thesis is brought to you for free and open access by ThinkIR: The University of Louisville's Institutional Repository. It has been accepted for inclusion in Electronic Theses and Dissertations by an authorized administrator of ThinkIR: The University of Louisville's Institutional Repository. This title appears here courtesy of the author, who has retained all other copyrights. For more information, please contact thinkir@louisville.edu. 
MAD AT MILES: A BLACK WOMAN'S GUIDE TO TRUTH

THEATRE BUILDING USING MYTHS, MOTIFS, AND ARCHETYPES

By

\author{
Triza Cox \\ B.S., Coastal Carolina University 2004
}

A Thesis

Submitted to the Eaculty of the College of Arts and Sciences of the University of Louisville

In Partial Eulfillment of the Requirements Eor the Degree of

Master of Fine Arts

Department of Theatre Arts

University of Louisville

Louisville, Kentucky

May 2012 
Copyright 2012 by Triza Cox

All rights reserved 


\title{
MAD AT MILES: A BLACK WOMAN'S GUIDE TO TRUTH THEATRE BUILDING USING MYTHS, MOTIFS, AND ARCHETYPES
}

\author{
By \\ Triza Cox \\ B.S., Coastal Carolina University 2004
}

A Thesis Approved on

April 18, 2012

By the Following Thesis Committee:

Dr. Lundeana Thomas, Thesis Director 


\title{
DEDICATION
}

\author{
This thesis is dedicated to the students \\ I have taught and \\ the students [ have worked with as a Teaching Artist. \\ The greatness I see in you ignites the art in me.
}




\section{ACKNOWLEDGEMENTS}

[ would like to thank my 'Thesis advisor and director, Dr. Lundeana Thomas, for a hl her guidance and Eaith in me. I would like to thank my thesis committee members professor Nefertiti Burton and Professor Skinner for their support through this process. I would like to thank my cast mates for their hard work, commitment and loving kindness.

I would also like to thank my dearest friend Brady Carnahan for being a joy and my rock. Finally I would like to thank my mother, Peggy Cox, my sister Valerie wright, my cousins: Diane Myers, Sharon Myers, Tim Franklin and my entire family for being there on this journey. 


\title{
ABSTRACT \\ MAD AT MILES: A BLACK WOMAN'S GUIDE TO TRUTH THEATRE BUILDING USING MYTHS, MOTIFS, AND ARCHETYPES
}

\author{
Triza Cox \\ April 18, 2012
}

This thesis chronicles my journey within the framework of a hero's journey, as a theatre artist in the Master of Fine Arts program at the University of Louisville's Theatre Arts Department. This thesis is divided into six chapters that explore the importance of using and understanding myths, motifs, and archetypes for character development in general and specifically for building the ensemble production from Pearl Cleage's collection of essays: Mad at Miles: A Black Woman's Guide to Truth. The Introduction explores the origins of the drive for humans to create art. 
Chapter One investigates my attraction to theatre through my personal life as well as from the metaphysical perspective of a Jungian collective unconscious. It also chronicles many of the trials and triumphs of the training courses and productions of the Theatre Arts Department. Chapter Two describes the circumstances and themes that motivated my interest in choosing Mad At Miles: A Black Woman's Guide to Truth as my thesis performance role. Chapter Three documents my process and the ensembles' process of creating this piece of theatre utilizing themes of the collective unconscious, archetypes, and team building. Chapter Four delves into the deep exploration of the archetypes I used as an actress to create several characters for the show. The Conclusion reflects on the lessons of the journey as well as how and where these lessons direct me to the artistic paths ahead of me. 
TABLE OE CONTENTS

PACE

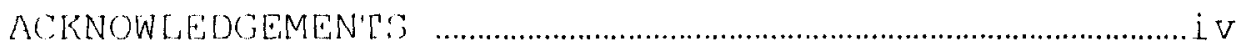

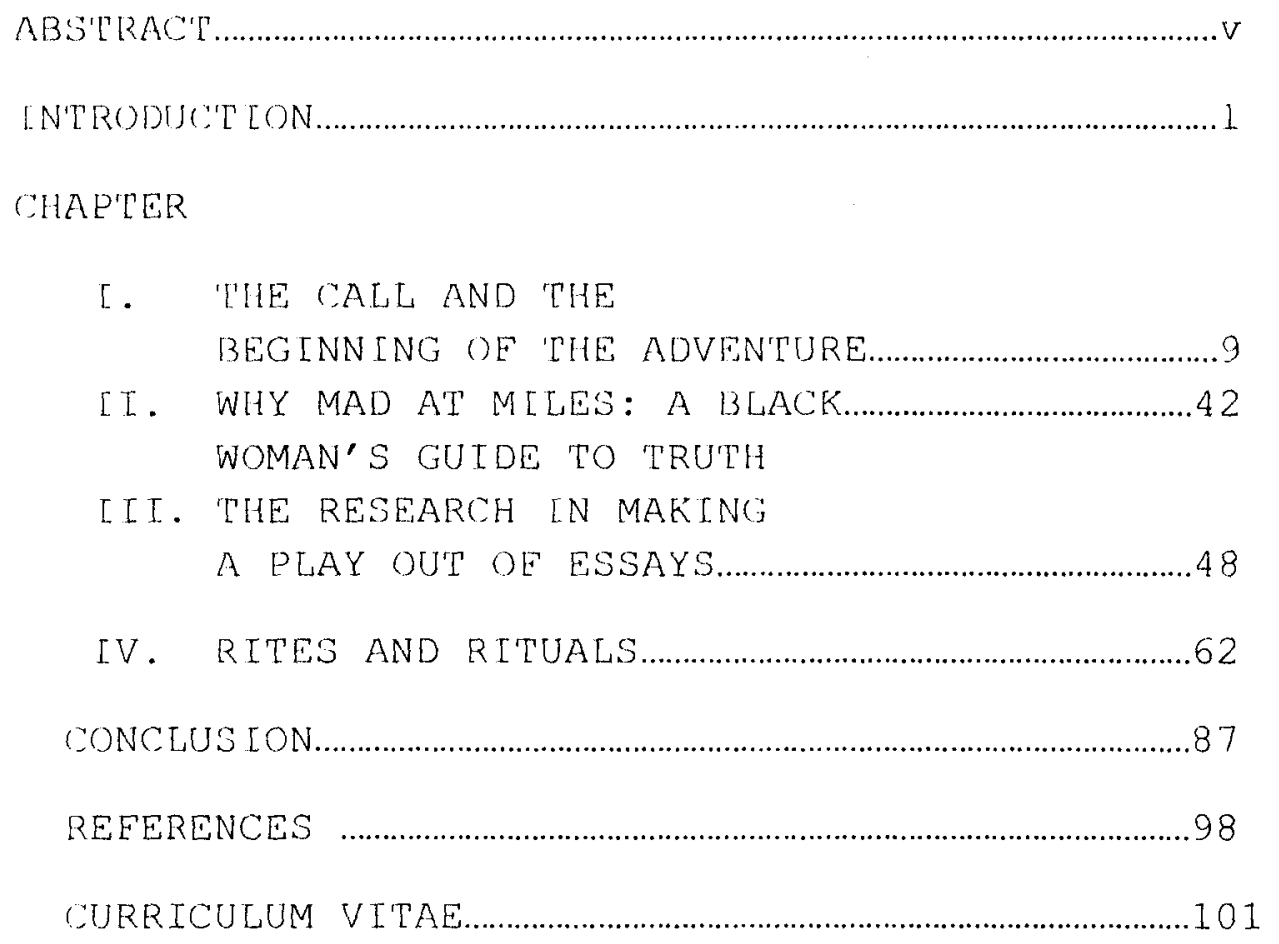




\section{INTRODUCTION}

As I approach graduation I have been reflecting on my life's journey and my journey to becoming a theatre artist. Why did I decide to enter this field with little job security, long hours and hard work? What was my compulsion and attraction to the stage when no one I knew in my tobacco-farming town in South Carolina had the same longing? To answer these questions and on transitioning into a full-time professional theatre artist, I began a journey of mythological and metaphysical reflection in the fall of 2011 .

The works of Carl Jung, Martha Graham, Marion Woodman, Joseph Campbell and other philosophers, artists, and scholars aided in my understanding of my journey. These works informed my personal growth as a theatre artist as well as my process and work for the thesis role in Mad at Miles: A Black Woman's Guide to Truth (Mad at Miles) by Pearl Cleage. From these works I discovered connection to 
the collective unconscious using archetypal energies, which allowed me to use my voice, body and imagination to create powerful performances that could transform my experience as an individual artist, the experience of the ensemble, and the experience of the audiences watching the performance.

First I shall examine the purpose of theatre in the framework of understanding myth and why myths have always and will always play a role in every culture. In Joseph Campbell's book, The Masks of God: Primitive Mythology (Masks of God) he examined the psychology and biology of human development that play a role in the necessity of myths and in the different recurring motifs that transcend a variety of cultures and time periods of human civilization. Campbell asserted that compared to other mammals human beings have an extended extra-uterine life. This extra-uterine life causes the human child to be dependent on the mother and have a longer period of immaturity that other mammals would have in the womb of their mothers. Campbell states,

The gift of immaturity itself, which has enabled us to retain in our best, most human moments the capacity for play. In puppyhood animals show a capacity for play, when they are protected from the dreadful seriousness of the wilderness by guardianship of parents; and practically all make a charming display of it again in courtship. However, in man or perhaps 
we should say rather in the best of men, though indeed in the majority of women-the capacity is retained throughout life (Campbell, 40).

This capacity for play is at the very core of human experience. No other creatures in the animal kingdom devote this much energy to pursuits that are not directly related to obtaining food, protecting themselves from prey or reproducing. Campbell espoused on the uniqueness of human play and the role of art in this need by saying,

Animals are without speech- and one reason, surely, is their inability to play with sounds. They are without art-and the reason again, is their inability to play with forms. Man's capacity for play again animates his urge to fashion images and organize forms in such a way as to create new stimuli for himself: sign stimuli, to which his nervous system may then react much in the way of an isomorph to its releaser (41).

In other words the need to play and create is a uniquely human experience. While it connects us to the physical and the metaphysical world it also becomes a distinguishing part of being a man or woman. I would also venture to say that art more so than industry, finance and romance is completely and innately human. These other pursuits of man are related to accruing wealth, shelter and procreation, which are all needs that are found in other forms in the 
animal kingdom. Wealth presents itself in the same instinctual need as accruing food resources. Art, however, serves no ostensible survival purpose, or at least in terms of the basic needs for human survival. Art does serve as a strategy, a method, and a resource for the survival of the psyche. Art allows the creators and the spectators to have a connection with the energies and elements that have been forces acting upon and within man since our arrival on earth.

I introduce this concept of play and image building to assert that theatre is at the very heart of this uniquely human experience. Good theatre allows the participants and audience to engage in play. This art form literally allows artists to act out various experiences and energies of what Jung refers to as the collective unconscious. Theatre also produces images of these experiences and energies. From the performance vantage point these images are created through the body, and the body's relationship to space, other bodies and architecture. Campbell's aforementioned extended extra-uterine development gives a sound argument for the innate human need of art. Furthermore this description legitimizes why human beings create art. 
Various myths, themes and motifs, particularly

theatrical representations of entities, are also examined in Campbell's The Mask of God. He states

Greek tragedy-was a poetic inflection of mythology, the tragic catharsis, of emotion through pity and terror of which Aristotle wrote being precisely the counterpart, psychologically, of the purgation of spirit affected by a rite. Like the rite, tragedy transmutes suffering into rapture by altering the focus of the mind. The tragic art is a correlate of the discipline termed, in the language of religion, "spiritual cleansing" or "the stripping of the self". Released from attachment to one's mortal part through a contemplation of the grave and constant in human sufferings- "correcting," to use Plato's felicitous phrase, "those circuits of the head that were deranged at birth by learning to know the harmonies of the world"- one is united, simultaneously, in tragic pity with "the human sufferer (50).

Here Joseph Campbell is asserting that dramatic tragedies

allow us to connect and tap into the human experience.

Moreover his reference of Plato's assertion about "the

harmonies of the world" connotes the collective unconscious Jung described in many works.

I chose to cite these paragraphs from Joseph Campbell's The Masks of God to denote the biological, psychological and sociological need of human beings to create art. This need shows itself in the various forms of storytelling from myths, fairytales and religious parables and allegory. There is a basic drive in human nature to 
create. Through the process of creating, the artist taps into the collective unconscious. Quality art resonates and evokes the energies that transcend cultures in the psyche of the human experience.

In the following quote Carl Jung gives a concise description of the collective unconscious:

The collective unconscious--so far as we can say anything about it at all--appears to consist of mythological motifs or primordial images, for which reason the myths of all nations are its real exponents. In fact, the whole of mythology could be taken as a sort of projection of the collective unconscious... We can therefore study the collective unconscious in two ways, either in mythology or in the analysis of the individual (Jung 325).

I contend that due to the biological and psychological

needs to tap into these motifs through creating and

enacting myths, the energies and transcending archetypes of the collective unconscious are the most important tools for a theatre artist. Theatre artists should understand and incorporate these motifs in character development and theatre building. These motifs are ancient while being modern. They are found in the stories of people from the East and west. The motifs are the personal and collective. Integrating the archetypes, motifs and shadows that present 
within the collective unconscious, teaches people how to Iive in the world.

The phenomenal power of mythological motifs is illustrated when we look at the box office success of films that depict the hero's journey. The hero's journey, as Joseph Campbell outlines and describes it, is an ancient motif found in myths, religious parables and legends around the world. Whether a person can articulate it or not, a hero's journey depicts an allegory in which our own internal and external personal growth is presented. The shadows or villains may look different, the boon may seem special, the supernatural aids may appear unique but the journey is the same. The forces that try to thwart all of us from our holy grails are mirrored in all these hero journey stories. The forces that aid us to discover our true selves are present too. I point out these facts of the hero's journey myth as an example of how quality art allows the artist and audience to connect with the collective unconscious.

It has become necessary for me to describe my winding path to becoming a theatre artist. I shall outline my personal journey within the structure of Joseph Campbell's description of the hero's journey. Campbell describes this 
journey in his book Hero with a Thousand Faces. I became introduced and interested in Joseph Campbell's study of myths when I was perhaps nine or ten years old. Coincidentally at the age of nine I conceived, wrote, directed, acted and produced a Christmas play in my fourth grade class. Perhaps watching Joseph Campbell explain myths ignited the young artist in me to create my own myth for and with my class.

I did not fully understand the hero's journey until I took a correspondence course in screenwriting in my twenties. Even at that point in my life I thought these motifs only applied to screenwriting. At this current moment in my life I am aware that understanding the hero's journey is beneficial to my understanding my personal path in my artistic and private life. I shall begin at the beginning . 


\title{
CHAPTER ONE \\ THE CALL AND THE BEGINNING OF THE ADVENTURE
}

\author{
Intelligent, creative, strong Southern ladies, \\ Amazonian ladies, raised me. My desire to be an actress \\ amused them to some extent but they were hyper-focused on \\ turning me into a doctor or lawyer so that I could \\ permanently claim my status in the black middle class. In \\ many ways their pressure caused me to always qualify being \\ an actress/something but never truly feeling comfortable \\ saying I wanted to be an actress.
}

A desire towards the performing arts made me the black sheep of my family. My longing to be an actress was alien to them. No one we knew had ever pursued such an outrageous dream. So where does that leave this little country girl who just wants to act?

I heard the call. Deep inside me I heard the call. I heard this call even when no one else could hear it. As I mentioned earlier I created, wrote, directed, acted, and 
produced a Christmas play for my fourth grade class. I mentioned earlier I created, wrote, directed, acted, and produced a Christmas play for my fourth grade class. I would watch every single PBS airing of "Great Performances" that showcased anything from Broadway musicals and dramas to New York Philharmonic concerts. I asked my mother to rent videos of Much Ado About Nothing or any other Shakespeare play I could view. I heard the call even when no one else heard it for me.

\section{Step Two: Refusal of the Call}

In the summer after my junior year of high school I asked my high school drama teacher to help me pursue theatre. She suggested that I intern at her theatre company in a small community just outside of Philadelphia, Pennsylvania. I accepted this theatre internship at Hedgerow Theatre Company in Rose Valley, Pennsylvania. I thought they were going to teach me how to act. I wanted to learn the craft. I wanted to learn technique. I wanted to learn to use my acting instruments of my voice, my body and my imagination. What they taught me instead was how to clean restrooms, pick weeds, and infuriate my mother over spending a summer away not making any money. Was the 
theatre business like this internship? Was it full of exploitation and broken promises? If it was then maybe I was not made for acting. So then and there I abandoned my dream and decided to follow the advice of the Amazons of my family. I went off to college and studied science. Medicine was tough but at least it was not exploitative.

After years of abundant science and minimal joy I graduated burnt-out and disinterested in pursuing a career in medicine. Jobs with benefits beckoned and led me to the world of public safety, retail, and banking. Money came in greater and greater supply but joy was more elusive. Ten years after my last internship in Pennsylvania, I auditioned for a local community theatre company's production of Las Cage Aux Eolles. I thought maybe this was my chance to reclaim my joy, but sadly it was not. What I discovered working with this theatre company was cattiness and more drama backstage than on stage. There was disorder, alcoholism, sexual exploits and the use of the word "nigger" behind my back. I was done with community theatre after this experience. I was not however done with theatre. Despite the chaos I still felt like I belonged in theatre. I just needed to find the right theatre experience for me. 


\section{Step Three: Supernatural Aid}

Despite the racism, exploitation, and chaos theatre caused in my life, I committed to the call to pursue theatre, at least as a hobby. Not long after I quit Las Cage Aux Folles I received a notice announcing the National Black Theatre Festival. I did not know if it was because I wanted to be exposed to Black theatre or because I just needed a vacation but I decided to go to the 2007 festival. My mother decided to come with me and this was when the change began.

I wanted to attend the festival as an observer. However, forces beyond my control had different goals for me. While waiting for the house to open for a play we were attending my mother struck up a conversation with a new playwright. That playwright needed an actress. My mother's response was, "My daughter is an actress". So when I walked up to them after returning from the bathroom the playwright said, "Are you a glass half-full or half-empty person?" 
I said, "Um, half-full?"

That exchange is exactly how I got cast in the reading of Not My Father at the 2007 National Black Theatre Eestival. One really terrific thing that came from working on this play was that I got to work with a real director. Ed Bishop was well known in the Washington, DC theatre scene and had also had worked at the National Endowment for the Arts. Bishop gave me a great gift. He treated me like a real actress and constantly referred to the quality of my voice as an acting instrument. My mother witnessed all these amazing experiences and for the first time in my life I had a degree of family support for my love of theatre.

When I returned back to South Carolina I was restless. There was just more predominantly white, bad, community theatre. Something in me said that I needed to start making black theatre in my small community in south Carolina. I emailed everyone I could remember and stated my desire to initiate black theatre in our area. One person responded.

Professor Keith Best chaired the Performing Arts Department at Francis Marion University. He graduated from the University of Louisville (University of Louisville and 
U of $L$ will be used interchangeably) with a Masters of Fine Arts in the early 1990s. In our communication I mentioned to him that I was interested in studying Alexander Technique and Stanislavsky. Professor Best put me in touch with Sarah Barker, a professor at the University of South Carolina, for Alexander technique lessons. Professor Best then gave me one of the most important gifts of my life. He offered to work with me for free, training me in the Stanislavsky technique.

Working with Sarah Barker started awakening a deeper creativity. Something changed in me and I decided to create my own work. I had recently endured a really hurtful romantic heartbreak, and I decided to turn my pain into art. I sat down and wrote about the experience. Those writings became my first one-woman show; Looking for Love.

Looking for Love was guerilla theatre at its best. I wrote, acted and produced this show completely on my own. I now realize that this show was presentation of the instinct in me to be a multi-faceted theatre artist. I chose a local restaurant as the venue for the show and when I walked in I saw a crowd of around fifteen people in the private room I used to perform the show. I originally thought they were just leftovers from happy hour but as I began setting up 
they said, "We came to see you." Maybe they saw the flyers I had strewn all over a thirty-mile radius. Berhaps they read a newspaper article that a reporter wrote about my endeavor. Whatever got the crowd to the show did not matter. What mattered was that people had come to hear what I had to say, and see my performance.

My show opened, and closed, February 8, 2008. At this point I committed to studying theatre and pursuing being a theatre artist, but I still thought that this would only be a part-time endeavor. By this time I accepted a management job at Woodforest Bank. I thought I should pursue a life in corporate America and act on the side.

For the next year I worked with Professor Keith Best more and more. We were progressing but I really had a small barometer with which to measure my growth. I knew I was getting better at attacking pieces than I was when I first went to the National Black Theatre Festival. I did not necessarily think I was good enough to do anything beyond the point of being a novice.

One day in January, 2009, Professor Best sent me an email stating that he was getting ready to take a group of students to the South Eastern Theatre Conference (SETC). He 
suggested that I attend the conference and register to audition for graduate schools.

\section{Step Four: Crossing the Threshold}

I must admit that by this point I was ready to move on from my small town in south Carolina. It turned out the corporate world was full of exploitation, manipulation, and dishonesty. Moreover I found myself feeling stagnate and needing more growth. I took all these sentiments as a sign that I should pursue graduate training in theatre. So I auditioned at the March, 2009 South Eastern Theatre Conference. One school made an offer. By August 2009 I was enrolled as a Master of Fine Arts candidate at the University of Louisville. This point marks step four of my journey. I had fully crossed the first threshold of being a theatre artist. I had left behind my old world of science and business in South Carolina. Now I was in the middle of the country for the first time. I accepted the University of Louisville without ever having stepped foot in Kentucky. I was embarking on transitioning from novice to professional. 


\section{Step Five: The Belly of the Whale}

In The Hero with a Thousand Faces Joseph Campbell describes the Belly of the whale as:

This popular motif gives emphasis to the lesson that the passage of the threshold is a form of selfannihilation... But here instead of passing outward, beyond the confines of the visible world, the hero goes inward to be born again (Campbell 77).

This feeling of being inside of the belly of the whale is such a beautiful metaphor for the agony of the training in this program. My professor, Dr. Lundeana Thomas, often states, that "We have to go through the agony to get to the ecstasy." Her comments may be true but I still try to examine whether the pain I experienced was growing pains or just a pain in the derriere. I shall describe the failings and successes of this training class by class and explore whether any ecstasy can and will come through these experiences. 


\section{Studying The Voice Method of Linklater:}

When I came to this program I was actually quite proud of my voice. I felt like it was articulate, strong and textured. At times I worried that my voice was overly nasal but I decided that my voice had smoothness and a sexiness that most actresses do not have. I worked previously as a disc jockey and had given several orations. What I did not truly understand prior to entering graduate school was how to use vocal power and resonance in a stage environment. Much of my stage experience had been with musicals or in intimate spaces. In these environments breath management was not as crucial as it had to be on stage.

The voice instructor in the program slapped me with a perplexing new neurosis about the quality of my voice. She insisted that my voice did not match my body type. During my first year she told me that I had a "little girl's body" and an older woman's voice. That statement made me feel like she wanted to engage in baby talk. I kept thinking, "Does this woman want me to talk like a baby? What in the world am I supposed to do with this information?" 
I now feel that the crux of what the professor was trying to articulate was that I have a wealth of resonators available for me. I tended to rely just on the chest resonators. Moreover, before my Linklater training I would rely on the chest resonators without allowing the breath to drop fully down to the pelvic floor. Part of my fear of not relying exclusively on the chest resonators was that I would not be able to generate the volume or the power if I utilized the soggy sinus valleys or dome resonators.

During the spring of 2010 I began to deeply explore the Linklater warm-up progression. My initial fear was that my neighbors in the apartment building would think I was crazy or talking to myself or having a nervous breakdown when I was warming-up every morning. My next fear was that without a vocal coach directly in front of me I would not be able to know if I was doing the warm-up correctly. In the end my neighbors did not seem too concerned with my daily work. Also, after two weeks of practicing every morning I quickly mastered the Linklater progression.

I had been unable to do a correct squat position of having my heels completely flat on the ground all of the previous fall semester. That spring the professor pulled me to the side and gave me a series of stretches that would 
open my hips and allow me to go further into the squat. Within a week of stretching for five minutes each day I was able to do a squat. Being able to properly enter into a squat allowed me to actually feel my pelvic floor and feel when the breath dropped all the way down to the pelvic floor.

In the spring when I started practicing Linklater I would begin standing and literally feeling the breath fill my abdomen and drop all the way down to the pelvic floor. Next I would curl down the spine and move into the squat. From the squat I would hit a touch of sound to a particular spot on the floor. I would then go down the scale while curling up the spine on touches of sound. After these touches of sound I would do faster touches of sound while dropping and rising more quickly up and down the spine. At the end of the progression of these faster touches of sound I would shake out the pelvis, the shoulders, and the hips. I would then stretch out the ribs and soft palate and tongue stretch. Afterwards I would work the chest resonators, mouth resonators and teeth resonators. I would then work the soggy sinus valleys. After the soggy sinus valleys I worked the nasal and back of eye resonators. Afterwards I would curl down the spine from working the 
chest resonator all the way to the dome resonator. I ended the warm-up working on the articulators.

As I have broadened my range of working with different productions I have added to and modified the aforementioned warm-up. During the summer of 2011 I worked with a Shakespearean actress, Maggie Lou Rader, who had a high level of Linklater training. Rader taught me to use lip trills, or raspberries, to strengthen the lips. She also taught me to do tongue drills where I would trace the inside of my lip line with my tongue ten times in one direction and then trace the opposite direction ten times. Rader gave instructions on pelvic floor strengtheners. One exercise I still use is to sit on the floor take a deep breath and bounce up and down while repeating two or more lines of my character's dialogue.

The tongue, lips, and pelvic floor exercises Rader taught me proved particularly useful when I play characters that have long speeches. I noted during the production of Mad at Miles that if I were not properly warmed-up in these particular areas I found myself stumbling and getting tongue-tied during my long monologue. 
Studying Linklater helped me understand the physiological dynamics of working with the voice. However, I find Linklater's imageries over the top and unnecessary. They can distract from the tasks at hand which are to warmup the muscles, resonators, bones and other components that contribute to creating a sound that works in all spaces. Never the less, Linklater did teach me not to push and force a sound through tension in the back of the neck or other areas.

\section{Studying Movement through Lecog Technique}

Movement class scared me from the beginning. What did I know about movement? Was this going to be in the same vain as the horrid gym classes I took in grade school? Would I experience the same humiliation of being the last one picked for kick ball? Would my body be pushed passed the boundaries it wanted to go? Well the answer to all these questions was yes. Movement class was an attempt to tear my self-esteem down completely. I liken this movement class to boot camp in white tights and white leotards.

I entered movement class having absolutely no appreciation for mime. The professor emphasized the pattern 
of seeing the object on the inhale, lifting the arm to approach the object and grabbing the object. Connecting mime work with the breath had a profound impact. The problem I had with learning mime was in the fact that the professor's pedagogical method is completely criticism based. He commented, "You have a sunken chest. You are flat footed," but he never told me how to correct these concerns. This teaching method only served to hold a mirror up to me and show me what I needed to correct but not how I was to correct it. Half way through spring 2010 I really became enraged with the professor. I felt he was shirking his responsibility to actually help me develop the muscle, poise, strength and balance that I had never had training to develop in my thirty years of life.

That rage sent me to dance classes. During the late spring and summer of 2010 I trained with the Louisville ballet, a belly dancing studio, and a salsa and west coast swing studio. These lessons awakened a drive that I had ignored for years. I love to dance. I was not certain that I was a good dancer, but I knew I had a love for dancing. This love was the beginning of the incorporation of using my body as an instrument to communicate the energy of the characters I portrayed. 
The second year of movement provided an opportunity for more growth. In second year movement we began mask work, which really allowed me to grow a great deal. One day the professor instructed the class to put on the neutral mask and perform fire. The whole class went through the process, and the whole class failed the process. The mistake the class made consistently was starting the fire from the extremities and externally. We would begin the fire from the fingers and the feet. The professor informed us that the fire starts internally. The fire starts from breath and from the core. The heat is a slow breath that builds and spreads to and through the whole body. I noticed this instruction faster than the rest of my classmates. On the second round of performances I started the fire from the core and from the breath. I then shot the flames out to the audience. I realized the energy of the fire was to threaten those around the flame. Later in the semester, we performed the ocean, winter, and sunshine. I realized that I could apply the energy of fire, snow, ocean and other elements to the energy of characters. This energy could inform the rhythm and style of the movement and speech of the characters. 
In spring of 2011 the professor began teaching commedia dell arte masks to us. The commedia dell arte class was the moment when I began to forgive the professor for what I deemed to be a year and a half of torture. The commedia masks taught me how to use many of the elements of comedy: surprise, exaggeration and others. The things for which the professor constantly criticized me for in the previous three semesters of movement were acceptable or even an asset in commedia. Strange body structures and strides proved extremely useful in creating characters.

The commedia dell arte class was the first and subsequently only class where character development was really pursued. This introduction to character development through mask work is an attempt to tap into what Jung describes as archetypes that repeat in myths, legends and tales. The stock characters of commedia dell arte are a sample of how archetypes give a frame of reference from which to build a character within the given circumstances of the particular play being performed.

Movement class taught me that creation begins in the body. At the very least my creation begins in the body. The body is the point with which I begin to tap into the river of the collective unconscious that allows me to create. 
Through movement class I recognized the importance of integration of the body and the imagination. The actor, or at the very least this actor, cannot act without the body being flexible, energized, ready and connected to the voice and the imagination. Moreover training the body will always be my lifelong endeavor and a necessity in order to help me create and work as a theatre artist.

Currently I have started pursuing yoga, dance and martial arts for my movement work. I noticed that many of my internal muscles are beginning to lengthen and stretch thus improving my balance, poise and grace. This Master of Fine Arts program should incorporate more of these movement elements. Incorporation of this training really allows the actor to correct and heal decades of bad habits while being able to use the body as an instrument.

\section{The Pseudo-Academic Approach to a Practical Art form: An examination of three unhelpful classes in this program.}

I would like to introduce this section of my thesis by stating that this program's scheduling of courses is horrendous. There is a complete disregard for the demands of a Master of Fine Arts candidate's need and development 
over the tenure of three years of study. My major point of contention is that the academic courses should be concentrated within the first two years of the program. Taking a Performance Theory class my third year while I am researching my thesis and preparing myself for the most difficult role at the University of Louisville was a set-up for disaster. Therefore, these courses did little if anything to aid in my development as an actress. The academic courses are absolutely not geared to help actors work on craft. As I write I struggle to find a purpose for clàsses such as Performance Theory class and the Tools for World Theatre class. I strongly suspect these classes were created for professors to try to legitimize themselves as academicians of theatre arts. This suspicion leads me to have an extreme irritation with the rampant selfish agenda pushing I find among the professors, staff and administrators in this Theatre Arts Department.

In academic studies I subscribe to the William James definition of Pragmatism. James stated,

A pragmatist turns his back resolutely and once for all upon a lot of inveterate habits dear to professional philosophers. He turns away from abstraction and insufficiency, from verbal solutions, from bad a priori reasons, from fixed principles, closed systems, and pretended absolutes and origins. 
He turns towards concreteness and adequacy, towards facts, towards action and towards power (James 51).

I encountered an abundance of bad a priori reasoning in many of the academic courses in the Theatre Arts Department. I suspect the source of these insufficient theories and verbal solutions was that often professors wanted to be experts in every discipline and did not stick to the discipline for which he or she received his or her degree. Professors in these courses wanted to be sociologists, psychologists, historians and activists instead of teaching how to approach and analyze a play. In the online publication of Backstage Magazine Peter Arcese, of HB (Herbert Berghof) Studios in New York, stated that actors should understand that in every script there is "patterned language." Arcese also states that, "Patterning allows the actor to fully embody the text by simultaneously engaging it intellectually, emotionally, and physically." (Horowitz par. 4) The Playscript Interpretation class never addressed patterned language in terms of how an actor used the language to understand sensory images and verbs to shape and mold the intentions and given circumstances of his or her character. The activities and assignments of the class were not geared toward anything an actor could use in 
his or her arsenal in terms of tackling a script. The assignments were the professor's attempt to bring in several elements such as design and playwriting into the course. This attempt of creative teaching left us with no foundation with which to approach a text as an actor. We never learned the term "Major Dramatic Question (MDQ)." We never learned translating the pattern of language on the page to patterns of language that would help inform character, rhythm, tempo and pitch choices. These shortcomings leave me thinking that the Playscript Interpretation class did little more than encourage me to read a few more plays my first semester at the University of Louisville.

My big contention with Performance Theory class was that this course gave the professor a platform for her unsupported theories on gender and race. She never had concrete evidence but spouted her theories as facts much in the same way Bill o'Reilly and Rush Limbaugh state their cases. For example the professor stated that Erykah Badu's nudity in her music video for the song "Window Seat" was a commentary on the "body of the black woman." I asked, "What makes you think that this video is a commentary on the body of a black woman? There is no reference to black culture or 
the black experience. If Joan Baez walked around nude in a music video is that commentary on the body of a white woman?" Again, the professor repeated her contention and offered no evidence to support her theory. This fetishism of Erykah Badu's choice to appear nude in a musical video is just one example of the weakly supported theories the professor stated throughout the semester. I find this method of teaching offensive.

The professor's response to my question was a perfect example of bad a priori reasoning. She had no empirical proof or experience that the statement that Badu made was commentary on the black woman's body. Erykah Badu tweeted that the "Window Seat" video was a commentary on "groupthink". She stated that we were all victims of "groupthink" and that the blood at the end of the video spells out "groupthink". Erykah Badu mentioned nothing in this tweet or in her website about race. Therefore, The professor projected that because Erykah Badu is black, being nude in a video is about her black body. Often in class, I had to point out inconsistencies in the statements the professor made. I feel that the department should revisit these courses so that they are tailored less for agenda pushing and more for text analysis, historical 
background, and other techniques that would prove successful for working actors.

\title{
On Stage at the University of Louisville: $A$ show-by-show reflection of performing in the Belly of the Whale
}

\author{
My first production at the University of Louisville \\ was the As You Like It. As You Like It was also my first \\ college production. Previously my work included solo \\ performances as well some community theatre. I quickly \\ learned that working with a wide range of students of \\ different competencies induced stress and challenges.
}

The major challenge to the As You Like It production was learning lines, blocking and intentions through the Shakespeare and Company's "dropping-in" process. "Droppingin" is a process where other actors feed you lines along with concepts to consider. The actor saying the lines never has a script in hand. Therefore you only use auditory skills to begin learning lines and developing character. An example of the "dropping-in" process would be with my character, LaBeau's lines, "Neither her daughter" the feeder would give me the line and then ask, "How does the 
word daughter taste? How does it feel?" After these questions I would say the line again with these

considerations. The "Dropping-in" process encourages an actor to get off book quickly because it is annoying to have another actor saying lines in your ear. From this experience I learned to ask myself questions when I would study lines at home.

As I have grown and matured as an actress and in life I began to understand my intense need for structure and regulation. When rehearsals feel a bit more out-of-order I do not have the meditative focus I need to channel the creative flow inside me. For the first couple weeks of rehearsal for As You Like It I found it very difficult to really feel safe and comfortable in the rehearsal hall. Also, the very small part of LaBeau made me have an immense amount of down time during the rehearsal process. With the young immature cast I felt the down time was uncomfortable.

In the spring semester of 2010 I was cast in The Laramie Project. What I enjoyed most about working on the Laramie Project was the structure of the rehearsals. The director did a great job of making rehearsals start on time and run in an orderly fashion. These attributes are all great management skills in terms of running a rehearsal. 
The drawback of working with this director is that he restricted many of the creative choices an actor makes. The production itself had no movement or momentum. He mandated that the actors have minimal interaction between the characters. He wanted a performance style that was completely stationary with direct audience address.

The great benefit of working on The Laramie Project was my introduction to playing several characters in one play. In The Laramie Project I played a Baptist Minister, an older sister, an emergency room doctor, a disc jockey and a Tectonic Theatre Project artist. These characters ranged in socio-economic class, gender, and races. Playing these characters was a lesson in technical acting in terms of how and where to pitch a voice for characters, rhythm and vocal patterns of speech, and vocal utterances and overflow. I also found certain physical patterns for each of my characters. The caveat became that most of the movement only occurred when I was moving into place. 


\section{Step Six: The Road of Trials}

Fall semester of 2010 ushered in a new academic year and a new show, The Colored Museum. The problem I have with writing about the experience with this show was that so much of the process was tainted by the bad behavior of the costume designer. I truly do not want to revisit this ordeal in my writing. The short version of the story is that the costume designer demanded that I cut my hair a week before the show opened. To non-theatre people this error may not sound like a big issue, but the costume designer's actions were seriously flawed. First off, it is against Actor's Equity standards and the standards for ALI professional acting companies, union or nonunion not to give notice upon casting or contract signing that drastic changes in hair are to be mandated if an actor accepts this role. The producing company is also responsible for paying for the change, which the costume shop never offered at the time of the request on september 26, 2010. The show opened October 3, 2010. According to the Actors' Equity rule book of the American Heartland: 
Change of Hairstyle. The Actor may not be required to cut the Actor's hair in a manner that changes the hairstyle or to shave the Actor's head, beard, moustache, or sideburns, unless the Actor agrees in writing at the time of contract signing. If the Actor agrees, the producer will assume the cost of making the change and maintaining it during the run. (Actors Equity American Heartland Rulebook 17).

It is also against the standard for most academic institutions. At the time of casting costume designers are to state these request, because an actor has the prerogative to refuse a role if the demands for changes in appearance are too drastic. Moreover I found the costume designer's statements to me coded with either her racism, or extreme ignorance. She stated, among other things that," You are a graduate student so you should have a more versatile hairstyle. ${ }^{1}$ I had a gut reaction that she meant a more European hairstyle. She apparently was completely oblivious to the fact of the plethora of styling options one has with dreadlocks. We had a few loud verbal feuds during the dress rehearsal where she tried to intimidate me and exert her so-called "authority" over me. I find this behavior particularly vicious. She verbally assaulted me

\footnotetext{
$1_{\text {The }}$ costume designer made this statement September 26,2010 one week before opening night and five months after I was cast in ALL parts.
} 
just before I went to places on the first night we had an audience. This behavior is the equivalent of me harassing a football player just before he goes on the field. This behavior is active sabotage. So after the run of the show I went to the Provost's office and asked for professional mediation. I asked for professional mediation in early October 2010 and did not get it until late January 2011.

The then chairperson of the department aided in the delay and chaos created by the situation by refusing to allow me to have an advocate in mediation from the Provost's office. The costume designer's minions wrote unsubstantiated letters to my graduate committee stating that my behavior during the show was unacceptable. They never offered any concrete evidence other than they just did not like me. The amateur psychologist in me deemed the costume designer to be what Carl Jung described as animus possessed. She is so aligned with the negative aspects of masculinity that her goals are to dominate, to humiliate, to scheme and destroy the development of graduate students like me. In my version of this hero journey she was a clear villain whose ultimate goal was to destroy my making it as a professional actress. In their letters, the costume designer and the costume shop manager wrote that I did not 
deserve to be a professional actress because I would sully the name of the University of Louisville's Theatre Arts Department. Let me assert at this time that the University of Louisville Theatre Arts department has NO NAME in the professional theatre world. I know of only ONE person in the forty-year history of the department who is a working actor. No University of Louisville Theatre Arts Department alumnus has been on Broadway or had a significant role in a successful film or television series. The costume shop manager has a Master of Fine Arts in Performance yet works as a costume shop manager and does COMMUNITY THEATRE. I came to graduate school to transition beyond community theatre. If the costume shop manager is an example of what the good name of the University of Louisville can do for you then I am concerned about my investment of time and money in this program.

I wish there were more I could say about what I learned from performing in The Colored Museum. In the end there was not enough time after the trauma of the costume shop's behavior toward me for me to analyze the work effectively. The costume designer's outrageous attacks on me made me want to leave the University of Louisville 
because I realized this department cared nothing for the actors.

In the spring of 2011 I accepted the role as Meridee in a production of Charles Mee's A Perfect Wedding. When I decided to do A Perfect Wedding I did not have a set routine to train the body for a performance. Therefore, while I was conscientious of keeping my voice and body warm and ready, my first and primary consideration for dealing with this new role was the text. When approaching the role of Meridee in A Perfect Wedding I attacked the text through literally wanting to feel the words in my mouth. I used a pattern of repetition to really hear what was being said in the script. I also used this drilling repetitive method to hear what different inflections, rhythms and vocal choices were available line by line.

Meridee has a long monologue, which jumps from second to third person voice. I carefully used the text to try to discover what the action was in the scene. After each line I would write an intention in the infinitive verb format. This method helped me basically create meaning on each line. The infinitive verbs also aided in my use of the Stanislavsky "magic if". Through the rehearsal process of the production I would ask myself, "If I were engaged and I 
had an unreliable flaky fiancé who ran off every time things were difficult or uncomfortable how would I say these lines? What would I do?"?

One issue I encountered with playing the role of Meridee was finding the arc to a piece. I subscribe to the notion that a play is a journey on which the production transports the audience. Within a scene or in my case a long monologue there are little journeys. Where was the climax? This question becomes tricky because the playwright, Charles Mee, loves philosophical tangents that have little action. His long speeches can feel like ramblings. I eventually found the climax to be on the second repeat of the line, "I keep waiting for my love for you to stop." Physically and vocally I tried to achieve this climax by dropping down and by freeing the voice to go into an unrestrained range. This unrestrained sound sometimes was a scream or a howl.

One big thing that constrained me as an actor was the director's instructions for me to deliver huge chunks of a long monologue in profile to stage left. There are technical problems with this form of direction. First,

${ }^{2}$ The full play script for A Perfect wedding is found at ww. charlesmee.org. The play script is not numbered and neither are the lines. This line occurs in Act I scene 5 
audiences can only endure long monologues if they can see the actor's eyes. The audience needs to view the internal battle manifested externally. Second, as an actor it was extremely difficult to maintain focus while stagehands and cast members gallivanted in the wings. Third, it just did not work. Because theatre is a practical art, it really comes down to what works and what does not work. An actor talking for a long period of time on stage by herself with her face completely in profile does not work and is a BAD choice.

As someone experienced in performing long monologues and solo performance I understand that a long monologue only works when there is a clear audience/actor relationship. This relationship is how the audience becomes invested in the character. The relationship is established through eye contact. The director repeatedly directed me not to look at the audience. That choice constrained me considerably. She also inhibited much of my movements and gave me line readings, which definitely inhibited my tapping into the unconscious river of creativity.

A Perfect Wedding proved to be a serious trial for me because of the director's misinterpretation of ideas for community-based theatre made the rehearsals chaotic. Her 
over-directing me and mandating that I employ her bad choices truly made me resent her as a so-called theatre artist. I acquiesced on so many of her choices because I felt disempowered after the three month battle with the costume designer and subsequently the former department chair. I truly felt like I was not in an empowered place to stand up for myself or my choices in this program.

This feeling was confirmed by a statement the former department chair made during an episode where he confronted me for so called terse emails. He told me, "You have a problem with authority. Actors have no authority." ${ }^{3}$ First of all I do not have a problem with authority I just have a problem with incompetent malicious power hungry maniacs. Second of all, actors do have authority even if it is just the power to walk away. I found his statement extremely frightening. It really resonated to me as the same energies predators use. I felt this department was a hostile environment, and I did not feel safe.

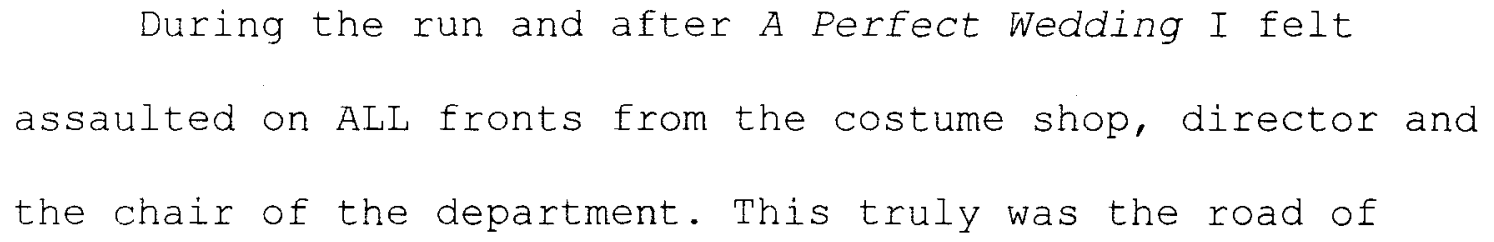

${ }^{3}$ January i7, 2011 after the African American Theatre Program's Dr. Martin Luther King Day celebration 
trials. I was not safe in this department and I began to feel it every time I crossed the threshold into the doors of this department. Moreover by the end of the semester I received horrible reviews from the faculty. Here's a big surprise: EVERYTHING, they criticized about my performance had been a directions given from the director. When I brought this fact out in my committee meeting the professors admonished that I should have saved myself. You know you are on the road of trials when the so called authority figures are gunning for you and the so-called advocates say, "Save yourself." 


\section{CHAPTER TWO: WHY MAD AT MILES: \\ A BLACK WOMAN'S GUIDE TO TRUTH}

The chaos with the costume designer's outrageous and unprofessional behavior tainted and tempered most of my second year in the program. I spent the end of fall semester and all of spring semester plotting and planning on how to leave the program. I described this state of mind because I soon realized towards the end of spring 2011 that I needed a thesis show if I could not figure a way out of the program. I originally wanted to do The Amen Corner by James Baldwin or a Greek Tragedy like Medea. The problem occurred with how political the department is run. The faculty members have grudges from years past and so I never felt empowered in a manner that I could present a list of shows and say which one I wanted. Dr. Lundeana Thomas eventually gave me two scripts to consider: Shaking the Mess Out of Misery by Shay Youngblood and Mad At Miles. 


\section{Step Seven: The Meeting With the Goddess}

The upside of Mad at Miles was that I felt like it was a performance art piece and similar to many of my own original works that I produced. In the spring of 2011 I wrote my one-woman show entitled God in the Midst of It All. This show came out of our spring semester acting class with the professor. Through this class we created original solo pieces and basically work-shopped the performance with professor and our peers. In this show I follow the journey of a woman from age five to age thirty. Her journey starts in South Carolina in the heart of Jim Crow. During this time period the protagonist, Mary Mae, encounters the brutality of racism through the lynching of her friend, Manuel. The second scene of this thirty minute show opens with Mary Mae starting South Carolina state College. While studying at college Mary Mae meets the second love of her Iife, Malik, and decides to participate in more radical acts of the Civil Rights Movement. Her participation in 
these acts land her in jail and she must reconcile the injustices and the atrocities through which she has lived.

God in the Midst of It AlI was my third one-woman

show. It was however the first one-woman show that ignited my foray into social justice theatre. As an undergraduate I had a strong background in social justice work on campus. While at Princeton University I was vice president of the National Association for the Advancement of Colored People (NAACP) and we lobbied for African languages to be offered in course studies. While at Coastal Carolina University, I was a member of a group called People Against Violent Encounters (PAVE) and we lobbied and campaigned for the University to recognize the problem of sexual assaults on and near campus. Despite my attraction to social justice causes, I often found that working with social justice organizations worked my emotions. Additionally the groups were not as committed as they should have been. They never achieved their stated goals and often broke apart after less than a year of being organized. After my last tenure as an activist I decided to take a more middle road approach rather than an activists' approach. I noticed that most of the activists I knew were more talk than action. I found activism to be a lifestyle for people who were 
already firmly ensconced in the middle class. My modest financial beginnings mandated that I concentrate on establishing myself financially.

With my aforementioned history, I never sought social justice theatre. Social justice theatre found me. Here is where I met with the all-encompassing divine love that is described in the "Meeting the Goddess" step of the hero's journey. The story of God in the Midst of All came to me in a morning as I was preparing to go to the dentist. The dialogue, the characters' voices, everything just presented itself. This presentation was my encounter with the creative goddess that had no agendas nor motives other than to tell this story. Everything that I had endured before was preparing me to tell this story. Speaking the words into being was a communion with a higher power that I had never experienced before this moment. I literally started talking to myself as I made my bed and brushed my teeth and the speech was the characters voices. The first scene came to me this way. The second scene had to be worked and reworked with me using writing exercises from a screenwriting book. However the immediate and the more laborious creative efforts were both communions with the 
goddess. Creating God in the Midst of It All also began my taking myself seriously as a professional theatre artist.

Let me take this time to say while the professors praised my work none of them helped me develop and pursue getting this piece produced in other places. The department did nothing to encourage and support me trying to develop this solo performance. They perpetuated a complete lack of career planning despite my very vocal desire to have solo performance work as a part of my career path. In fact the department brought in the American College Theatre Eestival to see two undergraduate original works but none of the work of those of us who really were serious about making a career as solo performers.

My second social activist solo show was commissioned by the office for Prevention, Education, Advocacy on Campus and in the Community, also known as PEACC, for Take Back the Night. I wrote and performed an original ten-minute piece called Walk Tall. These two pieces serve to reveal my natural calling for solo performances, performance art, social justice pieces, experimental pieces and character development. 
I explain my experiences with walk Tall and God in the Midst of It All to explain my attraction and fear of my thesis show. Upon first reading of Mad At Miles one could interpret Pearl Cleage's essays as a vilification of men and of promoting the victim archetype for women. So in the spring of 2011 I was communing with the goddess about creating my own solo pieces and wrestling with her over whether or not I should do Mad At Miles as my thesis show.

By the end of spring 2011 I did not want to come back to graduate school. The only reason I did come back to graduate school was because I had not discovered other means of full time employment. I did, however, earn my living over the summer of 2011 as a professional actress, despite the villains of this journey stating that I would sully the name of this theatre arts department. 


\title{
CHAPTER THREE \\ THE RESEARCH INVOLVED IN MAKING A PLAY OUT OF ESSAYS
}

\author{
Jungian terminology, particularly the concepts of \\ archetypes, became vital to the process of creating my \\ performance of Mad At Miles: A Black Woman's Guide to \\ Truth. Understanding the idea of "numinous" a term derived \\ from the Latin word numen, which means Divinity, or god \\ (Oxford English Dictionary) proved to be a vital foundation \\ upon which to build characters based on energy systems. \\ Many Jungian scholars describe numinous as originating from \\ the ancient belief in animism. Animism asserts that all \\ natural things have souls. Dr. Angela Jaffe, who trained at \\ Jung's institute in Zurich, Switzerland, described \\ numinous images and symbols as originating from the \\ unconscious and thus having the power to change us \\ (Platania 76). In A Critical Dictionary of Jungian \\ Analysis, samuels et. Al. defines numinous as \\ Dynamic agency or the effect not caused by an \\ arbitrary act of will. On contrary it seizes control of the \\ human subject, who is always rather its victim
}


than its creator. The numinosum--whatever its causes may be an experience of the subject independent of will. The its creator. The numinosum--whatever its causes may be an experience of the subject independent of will. The numinosum is either a quality belonging to a viable object or the influence of an invisible presence that causes a peculiar attraction of the conscious (Samuels 100).

I have taken this time to list various scholars' understanding of numinous to arrange a preparation for the universal characteristics of archetypes. Platania describes archetypes as archaic remnants of psychic history of the human species. He quotes Jung as saying that,

An archetype is a phenomena of numinous or God--like dimensions. The archetype is in a very real sense alive and functioning in the world. The archetypes thus have their own initiative and their own specific energy. These powers enable them both to produce a meaningful interpretation and to interfere with a given situation(Plantania 58).

From this understanding of numinous and Jung's description of archetypes I have understood that archetypes are energy systems that provide a platform for understanding the forces that act within and around human beings.

Jung further went on to differentiate archetypes from personal complexes. Personal complexes stem from individual 
history while archetypes originate in our collective history. Jung stated,

The collective complex gives rise to mythical systems, ideals and values that are of a universal quality. They are thus formulated in response to the universal aspect of the human experience. They exist to explain, to compensate, to understand and to give meaning to creation and life, to destruction and death. (Platania 58-59).

I contend that ALL characters in every form of drama are derivations of archetypes. These archetypes may present varyingly due to the different given circumstances of sociology, era, and other factors. Characters may also be integrations of the specific archetypes and the shadow figures of these archetypes. Investigation and analysis of dramatic characters will always show a dominant energy system that motivates the character and influences how he or she operates within the world of the play.

Applying archetypal interpretations to Mad at Miles: Guide to Truth became essential because there were no characters written into the text. In fact the text of Mad at Miles was a collection of essays that playwright cleage originally composed to inform her teenage daughter about some of the dangers of dating in the late 1980s. Pearl and 
her husband, Zaron Burnett, Jr., performed sections of the essays in clubs in the Detroit area but cleage never developed the piece into traditional play structure. My conversation with the costume designer, Dr. Daryl Harris, Eurther confirmed the need to use archetypes as a basis for character. In the first week of rehearsal Dr. Harris conducted a design presentation in which he revealed that the costumes would be white leotards with flowing dance skirts. Dr. Harris also to state that the actresses would have slashes of red located in different places on their costumes. He explained that the rationale behind the design was that each actress represented the ghosts of women who had been abused due to intimate partner violence. I extrapolated upon this concept by deciding that I was not only the energy of survivors of domestic violence but also the energy of those who speak against domestic violence. Thus the proverbial stage was set upon which to build my characters.

The teachings and writings of Carl Jung and Joseph Campbell informed a great portion of my dramaturgical research for Mad at Miles. On October 5, 2011 I visited the Louisville Center for Women and Families to get an understanding of the sociological and financial pressures 
which factor into domestic violence. My interview with a counselor and training coordinator, Jessy Haywood, from the Center for Women and Families helped me understand the psychology of toxic relationships. In toxic relationships the abused and the abuser feed off each other. According to the counselor women or men in relationships of intimate violence will often identify abuse with love. A pattern of provoking partners to encourage violence will be highly prevalent in these toxic relationships. The need for abuse on both sides does not condone or excuse the action of the abuser. My visit to Louisville's Center for Women and Eamilies helped me have a sociological and political understanding of abusive relationships. I extrapolated further upon this understanding and went on to discover the archetypal energies that would present the backdrop of domestic violence.

Jung proposed that the many archetypal complexes could fit into the following categories: the ego, the shadow, persona, anima/animus, the self, the Mother, the Father, the Puer/Divine child, Kore/maiden, the hero, the Trickster, the Androgyne and the coniunctio. Platania describes how all Jungian archetypes could be constellated around four basic patterns of human activity. These 
patterns were described in terms of masculine and feminine. The Jungian concept of masculine and feminine are not genetic or phenotype characteristics but energy descriptions that are akin to the Hindu characteristics of Shiva and Shakti or the Chinese Yin and Yang systems. The four basic patterns of human activities are static feminine, dynamic masculine, static masculine, and dynamic feminine.

The static feminine exhibits energy qualities of interdependence and being undifferentiated. In the positive aspects the static feminine makes group life possible. In the negative or shadow form static femininity demonstrates devouring energies where the fate of the individual is sacrificed for the sake of the group.

The dynamic masculine energy expresses itself through initiative and action directed toward a goal. The negative presentation of the dynamic masculine energy includes excess and destructiveness. The static masculine energy displays the tendency toward organization of the individual into systems of order. This energy establishes hierarchical social organization. The shadow of the static masculine can lead to order and organization for its own sake. The dynamic feminine moves toward the new and is non-rational, 
playful, and interested in the flow of experience. The shadow of the dynamic Eeminine complex presents can lead away from synthesis towards disintegration and chaos. According to Platania as a person becomes more integrated their energy moves into a continuum between these four quadrants of human behavior (Platania 60-64).

The first scene for which I needed to create a character was "The Time Before the Men Came." I called my character in this scene High Priestess Pearl. Her archetypal energy is that of the mother. Jung describes the mother archetype as:

The qualities associated with it are maternal,
solicitude and sympathy; the magic authority of the
female; the wisdom and spiritual exaltation that
transcends reason; any helpful instinct or impulse;
all that is benign; all that cherishes and sustains
that fosters growth and fertility. The place of magic
transformation and rebirth, together with the
underworld and its inhabitants are presided over by
the mother(Jung 82 ).

Her energy quadrant would be of the static feminine whose main concern revolves around grounding and connecting the group. I created a back story where High Priestess Pearl was the leader of the cult of women who worshipped the Hindu goddess Kali. I chose Kali because of her black skin 
and representation of beauty, destruction and creation. Kali is often depicted as the feminine force in many pieces of Indian Art. Around the fifth and sixth century a sacred Hindi text called Devi Mahatmya, which means the "Glory of the Goddess", tells the story of the creation of the goddess Kali. Kali is a black woman with four arms. In one hand she holds the head of a dead demon, and in another a sword. The remaining two arms are opened wide to embrace worshippers. Scholars like Joseph Campbell interpret Kali as representing the creative and destructive sides of femininity. The cult of femininity Pearl Cleage describes in this section of Mad at Miles is referred to as Amazons. These Amazons are warriors as well as creators of art and life. This cycle of creation and destruction lends itself to this cult worshipping a goddess of destruction and creation. As the Great Mother archetype, High Priestess Pearl nurtured and cared for the group and acted as their civic leader, general and spiritual advisor. The second scene of Mad at Miles was called "Last Day of the Year." Again I chose the Great Mother archetype for this character. Pearl Cleage wrote this section based on an actual experience she had of rescuing an abused woman from 
intimate partner violence. I called this character Mother Pearl. The car in which the Mother Pearl brings the young woman escaping domestic violence evokes an elemental energy of a uterus, which provides a safe nurturing place where Mother Pearl allows the characters to nest. Mother Pearl's driving goal in the "Last Day of the Year" is to keep her daughter safe as well as the young woman she rescues.

The third scene of Mad At Miles was called "Mad at Miles." This scene transported the ensemble into a dimension of supernatural forces. I chose the trickster archetype for this character and called her Poet Pearl. Jung's interpretation of the trickster archetype was based on the energy of a character that challenged authority. Many people define the trickster as Jung describe the alchemical figure of the god Mercury for having, "fondness for sly jokes, malicious pranks (and) powers as a shapeshifter" (Jung 255). Jung detailed his description of the trickster archetype by noting the Native American shamanic attributes of a trickster in:

His universality is so co-extensive, so to speak, with that of shamanism, to which as we know the whole phenomenology of spiritualism... at all events the "making of the medicine man" involves in many parts of the world, so much agony of the soul that permanent psychic injuries result. His approximation to the savior is an obvious consequence of this in 
confirmation of the mythological truth that the wounded wonder is the agent of healing(Jung 257).

Through these descriptions, the trickster enacts suffering and healing. The trickster exhibits dynamic masculine energy and thwarts convention by "calling out" Miles Davis's crimes against women. Poet Pearl tries to incite fury over the outrageous conduct of the musician by repeating the mantra, "Miles Davis is guilty of confessed violence against women. Such that we ought to break his albums, burn his tapes, scratch up his CDs until he acknowledges and apologizes and agrees to rethink his position on the woman question." This refrain repeats four times in the text. On each repeat new characters added on to the refrain. The refrain builds momentum and excitement that is intended to stir up rage and action among those who will hear it.

The fourth scene in the play was "In America." In this scene my character, Truth Teller Pearl, heralds the facts of violence against women. She and the ensemble announce to the audience the reality of the problem of intimate violence against women. The goal of the announcement is to motivate those who will hear the truth that the problem of 
intimate partner violence is real and must be taken seriously. I chose the archetype of the mother because as a group the six members are a collective voice speaking out to encourage awareness for these issues. Truth Teller Pearl leads the group and becomes the grounded energy system for which the voice of the group draws its strength.

In the fifth scene entitled "Self Defense" I utilized the archetype of a woman who was animus possessed. The animus side of her nature was the masculine side and the possession was the shadow side of the incarnation that dominates the woman. I called this character Fighter Pearl and she draws her energy from the dynamic masculine quadrant. She was completely aligned with the masculine dynamics of goal orientation that there are no feminine energy qualities in her psyche. Her quest was to defend herself and her cult of femininity. Fighter Pearl encourages those around her to understand and utilize their physical strength to protect themselves.

The sixth scene was "Solitude." In this scene my character was the Sensual Pearl. She was based on the archetype of the Self. The Self archetype enjoys balance between all four quadrants of the feminine and masculine systems. Jung describes the self as "the wholeness that 
transcends consciousness. The goal of the individuation process is synthesis of the Self" (Jung 164). The sensuality of this scene was the beginning of my character exploring the love of self and valuing self-care and selfLove over love of another. The archetype of the Self exists as the union of the conscious and unconscious. Stefan Gullatz articulates Jung's description of the Self as "a numinous image of psychic wholeness that becomes manifest in any mystical or religious experience" (Gullatz 123). A quote by Indian spiritual leader, Meher Beba, best exemplifies the importance and process of the Self archetype. Beba states, "It is you whom you are seeking and it is you who are sought. This is the Divine romance in which the Lover becomes the Beloved in the Eternal fact of God as infinite love (85)." The archetype of the self is the goal for every spiritual journey.

Party Pearl was the character I utilized in the seventh scene we called, "Real love." This character was young and questioned the status quo. She represented the trickster archetype. In the "Real love" scene Party Pearl provokes the question of whether there is an alternative to accepting domestic violence from celebrities. Party Pearl also questioned whether there was a justification or 
rationalization for accepting violence if the men were musical geniuses.

The final scenes of "Good Brother" and "Turn the Ships Around" brought me back to Peace Pearl. By the end of the play Peace Pearl's archetypal energy evolved completely to the energy of the Self. This manifestation of self stemmed from Peace Pearl experiencing coniunctio. The term means conjunction and archetypically represents the integration of the masculine and feminine energy patterns. Coniunctio is often referred to as a holy marriage or a union of opposites. In this scene Peace Pearl literally calls for the brothers to exhibit the positive aspects of masculine energy so that men and women may unite in a holy marriage. The energy of the character uses the polarities of static feminine and dynamic masculine as well as the polarities of static masculine and dynamic feminine. Peace Pearl, the character, embodied the continum of all four energy quadrants working together.

The Jungian lexicon of masculine and feminine energy systems as well as archetypes provided a foundation with which to build characters that evoked responses within the collective unconscious. As explained earlier tapping into the energy of the collective unconscious is the attribute 
of great art. Moreover since Mad at Miles: A Black Woman's Guide to Truth was a performance piece where the ensemble determined and created their character the Jung's lexicon became a necessary tool in theatre building. 


\section{CHAPTER FOUR: RITES AND RITUALS}

The process of developing Mad at Miles began at the moment of casting. I sat in on the casting process from start to finish. At first sitting on the other end of the casting table informed me of everything I have experienced as the auditioning actor. Dr. Thomas and I agreed on three monologues that were loaded with sexual innuendos, spirituality, political and mythological references. First I noted which actors owned the text and which actors let the text run them. By owning the text I mean which actors added technical vocal choices such as variations in tempo, rhythm, inflections, pitch and vocal variations. I also noted which actors made bold character choices after just a few minutes with the text. The most illuminating experience occurred when Dr. Thomas permitted me to give an actress a note. This auditioning actress kept bending at the waist and grunting on parts of the text that she deemed emotional. I advised her to plant herself firmly and stand 
poised, strong and erect. I also advised her to stop bending over because that action cut off her energy and made her seem less powerful. After I delivered this note the auditioning actress tried the monologue again and repeated the same bending gesture and grunts. This display taught me two things about auditioning. First, it tends to be more effective to make physical and vocal choices that send the energy out toward the other, acting partner or audience, as opposed to choices that direct the energy inwards. Second, the ability to comprehend and apply directions and notes is essential in the audition process. An actor who cannot apply the note proves him or herself a liability versus an asset to the company.

Mad at Miles lacked a script and characters, so it became excruciatingly clear that this project was an ensemble piece. The ensemble nature of the project also meant that casting played a principal role in the development of the piece. I dare say that even in plays with clearly defined characters and scripts casting was very much the backbone of the success of these conventional productions. In an ensemble based production where the cast and director developed the script and the character's casting was the back bone, the blood, the breath and the 
very soul of the production. In predictable productions the cast acts as a team. In innovative works such as Mad at Miles the cast and director arrived need to become the family where trust, love and cooperation reign.

The litmus test of who was going to become a family in the Mad at Miles clan occurred during the callback process. Incidentally I am aware that the term "Mad at Miles clan" evokes images of a cultish atmosphere. According to the Oxford English Dictionary the word cult has an etymology from the Latin word cultus, which means to worship, to attend to, cultivate or respect. The Oxford English Dictionary also provides several definitions of cult. Two of which we shall reference for the discussion of this process. The first meaning states that a cult is worship; reverential homage rendered to a divine being or being. The second meaning asserts a particular form or system of religious worship especially in reference to its external rites and ceremonies. The negative connotations of cult became popular in the twentieth century when obscure religious sects became notorious through allegations of child abuse, murder, physical and mental abuse as well as control. However, from examining the etymology of the word we can appreciate the original connotations of the word as 
referring to a group of people levoted to worship and their reference to something that could not be achieved through the individual but something that needed the whole. Therefore, Dr. Thomas and [ arranged the callbacks so that we could examine which actresses would be able to be a part of this family, which would be a cult of femininity.

Most of the women who came to callbacks had never before seen an audition process like this Mad at Miles callbacks. Our goal was to see how quickly and boldly the women could make physical, vocal and character choices. We also wanted to see how easily the women could be incorporated into an ensemble. The six auditioning actresses and I first came together in a circle and counted from one to twenty-five. In this practice each actress closed her eyes and took in each person's breath. We were going to count to twenty-five with no concurrent utterances of words. The application of the drill provided an opportunity to listen and intuit what needed to be said and when it needed to be said. I have been a participant of the counting exercise in my own acting classes and in acting classes I taught. Never in my life had I had such an intimate, successful and transcendent experience of the 
practice as I did during callbacks. We counted as one. We breathed as one. We were one.

The next step of the call back was for each actress to create a flower dance with music Dr. Thomas provided. Dr. Thomas offered no more instruction other than create a flower dance. This technique of minimal instructions proved an effective course of action. First it allowed the actresses to grow accustomed to relying on their own creative instincts and second it allowed Dr. Thomas and me to see the range of motion, contraction, expansion and rhythm of the actresses. Again the results astounded those watching the process. Each actress created a life cycle dance of the bloom and death of the flower. They incorporated many of the modern dancer's viewpoints of spatial relationships, rhythm, shape and tempo. The success of the dances informed Dr. Thomas and me that these actresses would be capable of creating a movement piece.

Dr. Thomas instructed the six auditioning actresses and me to create a machine that would beat men if they beat women. Initially the countenances of the actresses expressed trepidation over these directions. So I decided to dive in and positioned myself in a squatted position and informed the women that my body was the fulcrum of the 
machine and the others were charged to be the wings and handles that punished domestic abusers. Within seconds we created a machine that roamed the stage, charged, attacked and gyrated with the energy of metal and yet with a soulfulness of the individual components.

Following the glorious creation of the machine the actresses and I created a song about domestic violence. Again after receiving the instructions the countenances of the individual actresses betrayed their internal dialogue of, "What in the world are we supposed to do for this director?" So immediately I dropped and started creating a beat on the floor. The other actresses soon followed suit and we quickly had a song created. The song had singing, shouting, howling, tempo changes and rhythm. Later that night Dr. Thomas asked me what possessed me to start the song by creating a rhythm on the floor. I took a moment and reflected on this question. Why did I start by creating a rhythm on the floor? There was no intellectual reason of theory that I could provide. What I knew for sure was that at the moment when I looked into my acting partners' eyes my body said, "Give them a beat."

The final part of the callback process was creating a scene from the essays. We began staging a short passage 
from the section of the play that would later be known as "Self Defense." At this point in the callback process the cult of femininity was created and solidified. The aforementioned exercises and creations provided an atmosphere where the actresses felt safe and free to create. The scene came to life with unusual bold character choices. We then went on to create from "Before the Men Came." Given the mystical setting Pearl Cleage described in these essays the players immediately made even bolder character choices.

At the end of the callback evening, I knew something big was about to begin. It was scary but I was about to be a part of a significant experience. We knew that with the actresses we had a cast, we had a family. We had our cult that would carry out the rites and rituals of presenting a world of feminine wholeness and empowerment.

Monday, October 3, 2011 marked the first day of rehearsal for the show. Before I describe the first official day of rehearsal I would like to iterate an observation I recently noted to Dr. Thomas. I explained to Dr. Thomas that while I was studying Biology at the University of South Carolina and Coastal Carolina University I was often the artist among scientists. 
Recently as studying theatre at the University of

Louisville I felt as a scientist among artists. This sentiment harkens back to my aforementioned emphasis on pragmatism and my often noting that many of the classes put empirical evidence, time management and reason as low priorities on their agendas. I chose to reveal this statement to preface my feelings on the first night of rehearsal. We started the rehearsal process by examining and then discussing for over an hour which poster was the best publicity poster for the show. Everyone had an opinion, and everyone wanted to express it through what was tantamount to a thousand word essays the validity of his or her opinion. The pragmatic in me was screaming, "Who cares? Let's start the play!" Finally we did.

We had an initial reading where we got through about a little over a third of the essays. The first reading was interesting and I began to notice that the same bold choices I noted during the callback process were absent. The actresses were not reading with any inflections, vocal dynamics or intentions. They were reading in droning monotonous tones that reminisced of one reciting NASDAQ figures from the Wall street Journal. Even the more 
experienced actors were limited in their willingness to make bold choices in the reading.

By the second official day of rehearsal we finally made finished reading through all the essays. Afterwards the notes came. At this point in reflection I have to reiterate that Mad at Miles was my second main stage production with Dr. Thomas. I restate this fact to signify that at the start of this production I was well acquainted with Dr. Thomas's delivery of notes. An actor in a Dr. Thomas production can expect to hear: "How many keys are on a piano? Eighty-eight, well I want to hear eighty-eight keys in your voice! Give me some vocal dynamics." so on the second night of rehearsal, which was the first night of notes, the ears of the new actors to Dr. Thomas's productions became acquainted with a familiar Dr. Thomas's axiom of "I need to hear some vocal dynamics."

Early on in the process Dr. Thomas expressed to me that she wanted me to have a half an hour vocal and physical warm-up at the start of each rehearsal. After my experience as dance captain in Kathi Ellis's production of MacBeth I developed a new confidence and interest in movement. That confidence coincided with me having more physical training that included yoga, dance and combat. I 
chose to lead the physical warm-ups for the first week of rehearsal while Jocelyn Matsuo volunteered to lead the vocal.

The first week of rehearsal continued in much the same fashion. I led physical warm-ups while Matsuo led vocals. We began to break down the script, debated and discussed what parts of the text we wanted to use and what parts we did not. Again the pragmatic in me was challenged through this process. I often became vexed over the amount of time we spent debating whether a sentence or a paragraph was necessary.

At the end of the second week Dr. Thomas wanted us to take each essay in the collection and create names for the essays. The naming process was tedious, and points were debated at length. We finally decided on this list "Flying Amazons" for "Before the Men Came." "Write to Know" replaced "Why I Write." "The Sentencing" became the nomenclature for "Mad at Miles." The other names included "Testimony, Revelations, Understanding Clarity, and Can I Get an A-Men" Dr. Thomas never revealed to us her reasoning for having us debate at length. In hindsight I reckon that this process allowed the group to decide as a collective what each essay signified to us. 
Early in the process Dr. Thomas requested that I

create a ritual for the rehearsal process. After the second day of rehearsal I asked for a holding of hands and a meditation after the rehearsals. Often this meditation was in the form of a Judeo-Christian prayer. Often it was just a reflection on the process. One day during the second week of rehearsal I experienced a rough day among my classmates. As I mentioned earlier I spent most of the fall semester of 2011 vexed and aggravated over the poor planning of the department that demanded that I had the roughest course load that I had experienced since my first year in the MFA program. This aggravation was also present among my classmates and we started becoming more and more annoyed with each other. During the second week I had a particularly rough encounter with a few classmates. When I reached rehearsal that night I knew I needed to leave the troubles of the day outside of the threshold of the rehearsal room. I remembered the process of "candling-in" that I learned during a run with the Looking for Lilith Theatre Company in the summer of 2011.

$$
\text { "Candling-in" is a process where a candle is lit and }
$$
each member of the ensemble states in a one word or a short phrase something that they want to give to the candle 
before they start the rehearsal process so that the mind and spirit might be free to focus on rehearsing. After each member has stated her word or phrase, the candle is collectively blown out and the process the focus is now completely on rehearsing. At the end of the rehearsal we "candle-out." In the "candling-out" process each person states something she would like to take from the rehearsal process. Again the instructions are always to state this sentiment in one or two word phrases.

I repeat that the instructions stated to keep the statements for candling-in and out brief because after the first day of candling-in most of the cast members ignored those instructions. Instead of brief statements of what people got out of rehearsals we received ten-minute monologues on people's personal experience with domestic violence, mental illness, their theories on life, or just general angst. At these moments I wanted to scream, "This is THEATRE not THERAPY." What I realize now is that by the second week of rehearsal we had created such a safe environment that the ensemble felt comfortable revealing themselves. By week two of the rehearsal process we had not started blocking the show so I was less concerned with how 
comfortable the cast was and more concerned about getting the show on its feet.

After a grueling first two weeks of going through each essay and making cuts and line assignments, we had a workable script. By this time also we were becoming acquainted with the set. I must admit at this stage in my career at the University of Louisville I had become quite sullied with university designers. My experience with the costume designer of The Colored Museum and other designers in the program was that they designed not in service of the show but in service to their own egos. The costume designer of The Colored Museum once told me in October 2010 that actors were like sculptures with which to model her clothing. Later I informed her that unlike sculptures actors moved and had brains. The more we began working with the set the more I believed that the set designer was of the same school of thought to which The Colored Museum's costume designer ascribed. The set designer designed a set that he demanded we move and that nearly weighed eighty pounds. We were already a few solid weeks into the blocking and therefore his demanding that we move the set meant that we had to re-block the show. It definitely did not serve the show for us to do so. 
In addition to the set designer demanding that we move the set, the set was unsteady. I often felt that as I stood on the top of it I was literally surfing. A year before I began Mad At Miles I would not have been able to keep as much balance on a set that unsteady because my internal muscles were not as well developed. Yoga and kickboxing definitely helped me find the strength, balance and steadiness to maneuver the set. However, a set designed not to wobble would have been nice also.

The "candling- in and out" process became the ritual of the rehearsal procedure, but the onus was on the cast and director to create a ritual within the production. The scene entitled "Before the Men Came" references a sacred circle. Dr. Thomas implored us to create a circle dance and find a song for the circle. We originally started with an old hymn "We Are Soldiers in the Army." We changed the lyrics of the song to "We are Amazons in the army." We were able to write and edit a stanza of the song, but we found that we hit a block after the first stanza. At this point I remembered an ancient Navajo tradition of the "blessing way."

In a traditional Navajo blessing way the members of the tribe chant a blessing over the individual. Over time 
many non-Native Americans adopted this ritual of the circle chant to bring blessings onto an individual or group. These ceremonies often revolved around birth or marriage. On the website of www.birthbeads.com I found a chant used in the "blessing way" birthing ceremonies. The lyrics are as follows:

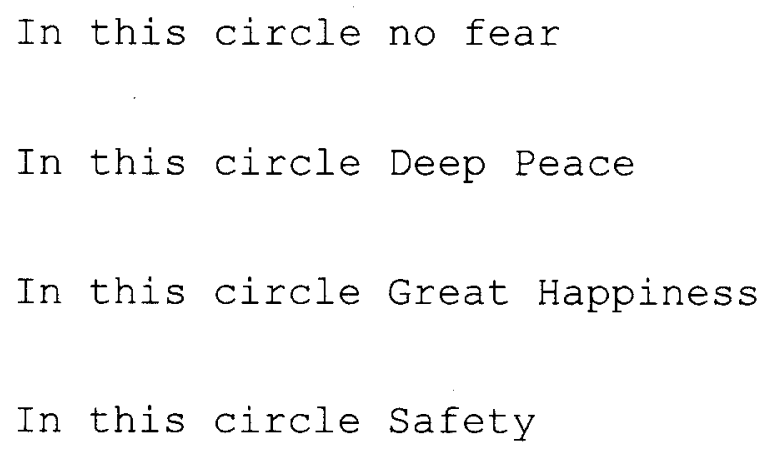
piano and pecked out a three-part harmony to the song. I asked my cast mate Jody-Ann Henry to lead the song and turn it into a call and response. She would sing a line and the cast would echo back in harmony. We worked on the song during the warm-up period. Afterwards we presented the song to Dr. Thomas. Dr. Thomas reflected on the song later that night and decided to amend and adjust our musical arrangement. We originally had a song with three part harmonies and individual trills and vocalizing. The caveat of the creativity of the arrangement was that the clarity of the words became lost in the midst of all the 
vocalizing. Dr. Thomas requested that we simplify the song with Jody-Ann Henry leading the call and response. She also wanted us to have a more grounded choreography. Originally we were dancing in the sacred circle with many pirouettes and other ballet moves. Dr. Thomas advised us to stomp in a two beat rhythm. The purpose of changing the moves from lyrical to more grounded served to show the characters' connection to the earth.

In the middle of the rehearsal process the cast previewed the show to five ladies from the Healing Place. The Healing Place is a recovery center in Louisville for people healing from substance abuse problems. The ladies who joined that rehearsal were not only in recovery from substance abuse but also from abusive relationships. That night they told us their stories. They also explained their struggles to stop identifying toxic relationships with love. They spent nearly four hours with us. Their time with us was a communion that allowed us to get a realistic understanding of the circle of violence in relationships. They also informed us that often as victims they would instigate violence verbally or physically because of their skewed sense that violence equated with connection to love. From their stories and from my archetype research I was 
able to get a clear three dimensional picture of each character.

As the piece developed more the ensemble realized that we needed coaching with our fight choreography. I had been taking kickboxing classes at Baptist East/Milestone fitness center in town. I contacted the instructor, Teresa Schmidt, and arranged an early morning training session for the cast. Two of my cast mates spent the night at my house and we all met at the gym at $7 \mathrm{a} . \mathrm{m}$. sharp for training. Schmidt cleaned up our fighting styles and helped us choreograph new sequences. In addition to helping the ensemble deliver precise performances, this training session allowed us to bond even more as a unit. It was team building at its best.

\section{Step Nine: Temptation}

As we approached opening night, a beautiful sense of readiness came over the cast. I presented a persona of focus and exhibited the attributes of a team leader externally. Internally I struggled with a feeling of imminent danger. I had a very real sense that the faculty and staff of the Theatre Arts Department were hoping for me to fail. 
At this point I found myself batting the age-old archetype of the devouring mother. An educational institution, or alma mater, can represent maternal clutches where individuation and independence is thwarted in order to cultivate codependence and obedience. The temptation I found myself confronting as we approached opening night was a very real need for approval from the proverbial devouring mother. I was second and third guessing myself because the voices of professors who cared nothing for my true success and growth as an actress and theatre artist were louder inside me than my own truth. I was tempted to approach this character completely from the vantage point of what would my acting professors want me to do. How would they say I needed to perform these roles? This conflict came to a head two days before opening when one acting professor made a comment about my performance in my shakespeare acting class. In her blind efforts to deem herself a psychic she stated that my monologue was off my breath because I was afraid to cry in public. My internal monologue was, "You don't know me," and at that moment I saw that statement for what it was. It was an attempt to undermine me as I approached opening night of my biggest show at the University of Louisville. It was also a fraudulent guru 
trying to assert power over me by so called "reading me." I sent this professor an email stating that while I would welcome any breath technique instructions she could offer I did not want or need her to cross my emotional boundaries. After that incident I realized that any temptation I had to have a maternal, or paternal, relationship with anyone associated with this Theatre Arts Department was a sign of my stunted growth. In order to be the artist and the woman I wanted to be I had to disassociate from the "devouring mother." I would not be embraced by this alma mater; I had to make art in spite of them, not to please them.

\section{Step Ten: Atonement with the Father}

I tend to believe that as a professional artist one must keep his or her private life private. I shall break my own rules here and explain how my personal path and artistic path collided on this journey.

My father and I had been estranged all my life. I knew only cursory information about him. I did not know if I had paternal siblings in the world. The summer after my first year at $U$ of $I$ I found his obituary on the Internet. He had died in the spring of 2010. Just before starting rehearsal I was in a phone conversation with the friend who drove up 
to Louisville with me Erom South Carolina to help me look for an apartment. I met that firiend when her mother asked me to direct her church's Christmas play in 2008. In our phone conversation this past fall I mentioned to my friend the details of my father's obituary and that my grandmother's name was Ola McAlister. My friend stated, "That's my great-grandmother's name."

It turned out that my friend was my first cousin's daughter. My father was her mother's uncle. My friend put me in touch with my paternal sister and we began weekly conversations. My sister informed me that my father portrayed Othello while studying at the University of south Carolina. My father had been a disc jockey and worked for South Carolina Educational Television. I had been a disc jockey and worked for Metro Television out of the mayor's office in Louisville, Kentucky. All my life I had been the black sheep of my mother's family, but I was my father's child.

Steps nine and ten set the backdrop of the personal growth that I needed to go into opening night. I deduce that the intensity of my personal growth stemmed from the importance of Mad at Miles. This show was bigger than the 
individuals. This ensemble was going to aid in teaching people how to live in this world.

\section{Step Eleven: Apotheosis}

The Merriam-Webster Dictionary defines apotheosis as elevation to a divine status. For the sake of the structure of describing my journey through this program and through my thesis project in terms of the hero's journey I really want to say that EVERY performance night was a state of apotheosis. The truth is each night ranged from no communion with the divine to complete divine status. At first dress rehearsal the ladies from the Healing Place and others formed an audience of about thirty people for us. That night I began to feel the apotheosis.

An athlete may describe apotheosis as the zone. For me it is the level of performance that is so intense that it enters into a state of aware meditation. You are completely present, but completely wrapped up in the world of the play and of the performance. Before the final dress rehearsal I left the dressing room twenty minutes before places were called. I looked at pictures of victims of domestic violence. I found a corner backstage and did yoga 
breathing, stretches and worked with my staff. When I entered for the top of the play something had changed in me. As I said the lines I was not directing the energy, the energy was directing me. I no longer was trying to induce a physical or emotional response for the character. The different characters' physical and emotional responses came of their own accord.

Opening night was another story. This night was the night I was the least in the state of apotheosis and I know why. Before the top of the show on final dress rehearsal I looked at photos of victims of domestic violence. On opening night I decided to go a step further with this idea and watched a video of Diane Sawyer's interview with a woman in a long-term intimate partner violence relationship. This decision to watch the video is a prime example of how theory does not always support practice. The video actually put me too far into left-brain cerebral mode instead of connecting me to the collective unconscious. That night the performance felt more pushed and I really had a hard time staying fully connected. It was the worst performance of the whole run.

The second night of the run occurred on a Thursday and here is where I learned something very interesting about 
how my body works in performance. I resolved to attend yoga classes each day of the run. However, many of the classes were much earlier in the day so there was often a gap of several hours before yoga class and show time. However, before Thursday's performance I was able to attend a performance that concluded just before call time. All I know is being very connected physically allowed me to get in an almost complete state of apotheosis for the entire show. This was a blessing because this was the night Pearl Cleage came to see the show.

Eriday night of the run was a disconnected night though not as bad as Wednesday. My belief is that the ensemble became over-confident over the warm reception Pearl Cleage gave Thursday night. Their over-confidence led to carelessness such as a cast member leaving her earrings on the set. I had to strike the earrings during the run of the show. The distraction and lack of cohesion in the group definitely made me have a harder time staying in the zone. I was able to achieve emotional connection with the character for brief moments, but I could feel the lack of focus. After the show the cast and the stage manager talked about these issues and we left with a resolve to have a tighter rest of the run. Saturday was much better. The 
ensemble and I had all day to rest, re-group and re-focus. I felt much more emotionally connected during the show. We were back on track.

Sunday marked the last day of the run and the first, and only, two-show day. Again, I did a yoga class that ended just before the call time. The Sunday Matinee ended being my best show of the run. Erom start to finish I felt completely in a state of apotheosis. I had a sentiment of being completely in the zone for the whole show. This experience confirmed my theory that connecting with the body very close to performance was the best way to connect with the character and the world of the play for the whole show.

Sunday night we closed the show and the ensemble was again a bit disconnected. The younger actors were scoping boys during the show and I definitely felt the lack of togetherness. Despite the ensemble's lack of focus by this point I was able to put myself in the place I needed to be for my own state of apotheosis. I had not quite hit the levels of the matinee performance, but I was still happy with the performance. 
The run of the show taught me that as a performer I start with the body to achieve the elevated state of focus required for performance. It also taught me that while I can be affected by the way in which the ensemble is cohesive I have techniques to find my own state of apotheosis. These lessons engendered me with a sense of confidence to head out into the professional world. 


\section{CONCLUSION : \\ STEP TWELVE: THE RETURN}

In 1988 Public Broadcasting Station (PBS) produced a Bill Moyers' documentary entitled Joseph Campbell and The Power of Myth. Moyers's recites a quote of Joseph Campbell where he instructs his students at Sarah Lawrence College by saying, "If you want to help the world, you have to teach people how to live in it"(PBS, 1988 documentary). This quote resonated with me on so many levels. I would like to add to Campbell's theory by saying to help the world you have to learn how to live in the world so that you can teach people how to live in it.

This theme of teaching people how to live in the world clarified for me that I could use theatre to enhance the world. Quality educational and entertainment theatre could provide opportunities for artists and audiences to understand universal forces. Upon reflection of my early days of creativity I realized that exposure to the themes, motifs and archetypes of the collective unconscious was 
what attracted me to theatre in the beginning. Campbell's what attracted me to theatre in the beginning. Campbell's quote also articulates my frustrations with the pedagogy of the Master of Eine Arts Program at the University of Louisville. There were many times I doubted they were teaching me how to be an artist that thrived in the world.

All of the acting courses in U of L's Theatre Arts Department centered on a Robert Cohen interpretation of intention. In basic terms the intention is the goal the character pursues in the world of the play (Cohen 22). The department goes no further in technique development other than actors understanding the character's goal, the others that affect pursuit of the goal, the tactics implored to achieve the goal and the expectation of achievement of the goal. This focus on Cohen's Acting one terminology is flawed pedagogically. It gives a cursory understanding of acting techniques, and furthermore, it does not take acting any further than the cerebral level.

As I had to do with movement, I needed to develop a more comprehensive technique to character development and performance. This need brought me to Jung and I began tapping into the collective unconscious to create powerful three-dimensional characters that were beyond the 
superficial level of the acting classes at the University of Louisville.

In 1997 Jungian psychoanalyst Marion Woodman appeared on the television show, Allan Gregg in Conversation on the Ontario Educational Communication Authority or TV Ontario (TVO) television program. During this interview she stated, "If experience is not coming from the body it is not known" (TVO 1997). I heard this quote after the run of Mad at Miles but it instantly resonated in my body. This truth was why my stronger performances were always after I had completed yoga. It was also why I found the pedagogical process of teaching acting at $U$ of $\mathrm{L}$ incomplete.

The acting classes tended to be superficial and intellectually based. There was very little in-depth training in developing character energies. For me I could use tools to imagine the character's energy and find it in the body. With Jungian archetypes I was able to get a vision of the energy of the character and then find ways to access that energy in my body. This technique was actually a more pragmatic approach. In real life, human beings may act without a cerebral understanding of the intentions of their actions. The deep drives and forces of the archetypal energies in their conscious and unconscious experience 
influence human beings. For the sake of art we can channel these energies to create vivid potent characters.

The first year I taught the course Acting for NonMajors I emulated the teaching style of my professors. I gave blunt criticisms that were more deconstructive than constructive. My experience as a student and as a teacher in the deconstructive criticism method informed me that this style of teaching does not empower students. It actually encourages codependence, resentment, and an abundance of self-doubt. I also centered my lesson plans on the Cohen Acting One book which proves inadequate in helping students tap into their creativity. I ended up having a VERY disappointing teaching year.

This 2011/2012 academic year was the year that my teaching improved. I chose to pursue a more holistic approach to teaching. I used a praises/suggestion/praise method to offer criticism. In this method I tell a student what was effective in the scene. I then offer suggestions for improvement. Finally I leave the student with what I enjoyed about the scene. I also employed and utilized many of Viola Spolin's activities in her Theatre Games for the Classroom. The games that required a plethora of movement proved to be the games that helped my student's "experience 
it in the body" so that they could express themselves creatively. Employing these teaching methods this academic year proved invaluable and helped me have a more successful teaching year.

The bigger benefit of adopting a holistic approach to teaching arose when I began discovering that my biggest successes in auditions and scenes were when I approached performing from a more holistic approach. The department's pedagogical shortcomings of focusing on cerebral reasoning instead of integrating the actor's voice, body and imagination nearly drove me to a neurotic doubt in my talent. I was only able to heal that doubt and become empowered on stage when I realized that my job as the actor was to prepare my voice, body and imagination as best I could every day and particularly before performances. I prepared my body through yoga stretches, dances and deep breathing. I prepared my voice through Linklater warm-ups, and I prepared my imagination through understanding the themes, motifs and archetypes of the world of the play.

I learned to read a play and evaluate what archetypal energy was present in the character. Writing journals in the character's voice from that understanding of their energy also became a great technique. I also discovered the 
benefit of taking each line in a scene and writing out what actions the dialogue suggested. Doing these exercises in the first days of receiving the script always aids in opening my imagination. The choices might evolve and change during the rehearsal process as my voice, body and imagination became even more integrated to create a character. If I applied these techniques early, at the point of production I knew I would be adequately prepared to turn the performance over to the divine so that I would experience a full apotheosis while performing.

I developed this technique on my own. No class or professor in the Theatre Arts Department ever suggested a concrete comprehensive technique for preparing for roles. As I began acting in more professional theatre companies I noticed that the most potent actors were the ones who had developed a specific preparation practice for their roles. One woman I worked with who trained at the Moscow Art Theatre creates a notebook where she writes out what animal her character would be and what song represents her character. This actress's technique resembles my methods of using archetypes because both inform what energy resonates in the character. Understanding and applying the energy of the character gives the performance a wholeness that allows 
the performers and the audiences to experience the character from a collective unconscious vantage point. Tapping into the collective unconscious makes quality art that can endure through the ages.

This journey of artistic development was riddled with conflicts and struggles. Repeatedly I felt that certain faculty, staff, and the program itself were trying to divert me from my path of becoming a professional theatre artist. However, the trials I endured led me to discovering Jung's theories of the collective unconscious. Learning more about the collective unconscious guided me to employing archetypes as a tool for character development. The personal struggles informed an understanding of the universal energies, motifs, and theories that allowed me to create powerful performances.

When I started writing this thesis, I was angry. I speculate I lost about $\$ 120,000$ of potential income in the three years of being here. So for a life of harassment and poverty as a graduate student in this Theatre Arts program I received limited training and no career development. I recently found myself walking in a park truly infuriated over this investment in time, money and dreams and the minimal return on my investment. 
The only thing that calmed me down was remembering the tune and Iyrics from the Marvin Hamlisch and Edward Kleban song from the Broadway musical A Chorus Line. The lyrics for "What I Did for Love" are as follows:

\author{
Kiss today goodbye \\ The sweetness and the sorrow \\ Wish me luck \\ The same to you \\ But I can't regret \\ What I did for love ... \\ Love is never gone \\ (Hamlish and Kleban 1975).
}

I know it is sappy and corny that I am quoting this song, but this is my story so I can be sappy and corny. It is also true. I did this whole experience because I love theatre and I love performing. I am painfully aware of the severe shortcomings of this Theatre Arts Department. In spite of the toxicity I experienced I would not have been able to become the Theatre Artist I am today had I not been at the University of Louisville. I do not and will not regret any of this experience. I have never loved anything or anyone as much as I love theatre at least not until very recently. 
Recently, I concluded an internship as a teaching

artist at walden Theatre. I toured a show called Journey: A Trip on the Underground Railroad (Journey) to over twenty elementary schools in the Jefferson County Public School System. Journey is a one-woman show of thirty minutes that chronicles a heroine's journey escaping slavery in Tennessee to freedom in Canada. After the show I would lead a talkback about slavery and the Underground Railroad. All I can say is that being a teaching artist showed me the contribution I could make to the world and community through my art. On February 3, 2012 I performed at cane Run Elementary school and the counselor told me before the start of the show that these were "bad" students and I may even need to stop the show. She was absolutely wrong. This school was one of my best audiences. I had their attention from start to finish. During the talkback they asked informed sophisticated questions. By the end of the show I knew I had provided an opportunity through my art for these students to concentrate and take themselves seriously. They were analyzing history and appreciating art. I was teaching them how to live in the world.

The 2011/2012 academic year has also been the most fun I have had teaching. As I stated earlier I centered my 
classes on physical development and team building. I employed many of the same principles we used in the ensemble building of Mad at Miles including ending each class in a ritual. My class ritual is a circle where we say an affirmation to our neighbor. I love these classes because I saw myself being able to lead a class towards working together and creating. Again, my art was teaching people how to live in the world.

I have a keen path before me of where my career will take me. I plan to move to New York City and perform, direct, and choreograph professionally. I plan to be extremely financially successful as an artist. I plan to explore opportunities on the stage and screen. I plan to continue training and developing my craft. These were my plans before I enrolled in the Theatre Arts program. Now, however, there is something more to this plan. I understand that theatre is a service. A theatre artist is a teaching artist. Through theatre we are able to see the themes, motifs and archetypes that are derived from our collective unconscious. Understanding these forces helped me learn how to live in the world. This understanding also helped me become a better artist and a better teacher. 
My whole life I struggled with really thinking that I had to contort myself into a scientist or a business tycoon or something "better" than what I thought I was to make some contribution to the world. It took me a long time to understand that being the authentic artist I am and always was would show me how to contribute to the world. The adversity of this program forced me to confront all the personas and facades and peel them back to get to my own archetype of Self. Jung once said, "I thank God everyday that I have been permitted to experience the inner reality of 'Imago Dei' in me"(Platania 91). The "Imago Dei" he described is defined mirror reflection of God. When I learned how to integrate voice, mind and body for a role so that I could experience the transcendence in performance and when I learned to be a better teacher I began to experience my own "Imago Dei." My journey through the University of Louisville's Theatre Arts Department brought me to this point. I am indeed grateful for this gift. 


\section{REFERENCES}

Barton, John. Playing Shakespeare. London: Methuen London Ltd., 1984.

Benedetti. Robert. The Actor in You. Fourth Edition. Boston: Pearson Education Inc., 2009.

Cameron, Julia, The Artist's Way. Tenth Edition. New York: Jeremy P. Tarcher/Putnam, 2002.

Campbell, Joseph. The Masks of God: Primitive Mythology. London: Penguin Books, 1959.

Campbell, Joseph. Hero with a Thousand Faces. Princeton: Princeton University Press, 2004.

Coburn, Thomas B. Encountering the Goddess: A Translation

of the Devi-mahatmya and A Study of Its Interpretation. Albany, NY: State University of New York Press, 1991. 
Cohen, Robert. Acting One. New York: McGraw Hill Higher Education, 2008 .

Gullatz, Stefan. "Constructing the Collective Unconscious." Journal of Analytical Psychology 55.5 (2010): 691-714.

Horowitz, Simi. "How to Approach Script Analysis?" www.backstage.com. Backstage Magazine. 6 May 2009. Web. 26 Dec. 2010.

James, William. Pragmatism: A New Name for Some Old Ways of Thinking. London: Longmans, Green and Company, 1910.

Jung, Carl Gustav. The Structure and Dynamic of the Psyche Collected Works). Vol 8. Princeton: Princeton University Press, 1970.

Jung, Carl Gustav. The Archetype and the Collective Unconscious (Collected Works). Vol 9. Part 1. New York: Bollingen Series, 1959.

Linklater, Kristen. Freeing the Natural Voice. Hollywood, CA: Drama Publishers, 2006. 
McGraw, Charles. Acting Is Believing. New York. Rinehart and Winston, 1966.

Moyers, Bill. Joseph Campbell and the Power of Myth. PBS Documentary, 1988.

Phillipson, Morris. Outline of a Jungian Aesthetic. Evanston, IL: Northwest University Press, 1963.

Platania, John. New York: Jung for Beginners. Writers and Readers Publishing Inc., 1997.

Samuels, Andrew. London: A Critical Dictionary of Jungian Analysis. Routledge and Kegan Paul Inc., 1986

Spolin, Viola. Theatre Games for the Classroom. Evanston, IL: Northwest University Press, 1986. 


\title{
CURRICULUM VITAE
}

\author{
Triza Cox \\ 3309 Colonial Manor Circle \\ \#3B \\ Louisville, KY 40218
}

\section{Education}

MFA, Acting-University Of Louisville

BS, Biology-Coastal Carolina University 2004

\section{Professional History}

Walden Theatre --Teaching Artist (2011-2012)-Dan Welch

Kentucky Historical Society Museum Theatre Actress (2010-2012) Greg Hardison

University of Louisville-Grad Teacher

2010-2012-TA 324-Acting for Non Majors. James Tompkins

2009-2010 -TA 227- Enjoyment of Theater Russell Vandenbroucke

Cardinals for Appreciation of Musical Theatre- Assistant Director and

Choreographer- Chicago-(2012) Spencer Scruggs

Blue Apple Players-Actress in Bullies (2011) Paul Lenzi

Looking For Lilith-Actress in Failure Is Not An Option (2011) Kathi Ellis

-Performed at Fort Knox

Louisville Metro TV-Intern/Producer/ Host (2010) Nicole Lechniak

Woodforest Bank-Branch Manager-(2008-2009) Tony DeSue

-Trained all retail bankers for local branch

-Developed marketing campaigns for branch

-Provided cash flow analysis for branch

-Educated customers on financial matters

\section{Volunteer Work}

University of Louisville Health Promotions- Sexual Health Advocate

Take Back The Night -Performance Artist-Walk Tall-- original solo performance 